\title{
The Impact of Cross-Border E-Commerce on the Problems of Chinese Economy New Norms
}

\author{
Xun Liu \\ Shandong Technology and Business University, Yantai, Shandong, \\ 264005
}

\begin{abstract}
As Chinese economic development into the "New Norms", in the new situation will be the next innovation for a long period of time to promote Chinese economic development of the new impetus. E-commerce itself has the advantage of innovation, is bound to be highlighted. Therefore, under the "New Norms", the e-commerce and traditional industries with the development of innovative model will bring us unlimited possibilities. Premier Li Keqiang proposed "Internet +" action plan, as an important derivative of the Internet e-commerce, for its sake is "e-commerce +." This includes "e-commerce + traditional industries", "ecommerce + finance", "e-commerce + new urbanization", and "e-commerce + import and export" these aspects. This is the main point of this paper from the analysis of the future strategic issues of e-commerce.
\end{abstract}

Keywords: Internet+, Chinese Economy, Cross-border E-commerce

\section{Introduction}

E-commerce in China show the development of blowout, but only in recent years, but in just a few years, Chinese e-commerce, whether in size or overall level, but are very good performance, not only in the world of electronics Business areas have a place, but also in enhancing the level of service platform, to build Chinese product brand on the road taken a solid step forward. Since 2000, the bursting of the global Internet economy bubble, making a lot of capital investment from the high-tech field, which makes just catch the Internet Express e-commerce has been a blow. For emerging e-commerce enterprises or by traditional enterprises onto 
the road of e-commerce enterprises, not only face the stock price decline brought about by the assets shrink, leaving them difficult to predict the market for ecommerce expectations, is the enterprise Whether the use of the Internet onto the road of e-commerce, in order to achieve greater value for money.

As we all know, the rise of the network in China, today, but also a short span of twenty years, e-commerce in China began only 10 years of history, but it created a different path of development in China. When the advent of the Internet bubble, China happens to feel the network in the bubble to bring fresh and convenient, limited by the development of market economy, China at the time did not have the conditions and basis for e-commerce, but for the future laid a solid basis. Because the number of Internet users in China with the popularity of the Internet surge, people's understanding of the concept of deepening of the network, which for the development of e-commerce has laid a good foundation. After 2005, Chinese e-commerce formally entered the rapid development of the road, during this period, the increasing number of electric business, online transactions continue to expand, with the online trading policy, development model and technology continue to improve, the overall e- An unprecedented trend of development. Especially after the outbreak of the financial crisis in 2008, Chinese foreign trade exports have been seriously hampered, relying on e-commerce in the cross-border electric business enterprises began to emerge, more and more electric business with domestic electric business development and accumulation of advantages, Actively explore the international market.

\section{The Basic Status Quo of Chinese Cross-border E-commerce Development}

In recent years, with the rapid development of Chinese economy, Chinese ecommerce market is booming, according to statistics, China has become the world's fastest-growing cross-border e-commerce countries, especially with the United States and Japan through cross-border e- The proportion of exports continue to increase cross-border e-commerce has become Chinese foreign trade development is an important driving force.

Since e-commerce has been restricted in the field of electronic commerce, foreign enterprises in China are subject to a number of restrictions on ecommerce, Chinese enterprises in order to open up international markets, and no sufficient funds and experience, and thus to cross-border e-commerce transactions caused considerable obstacles. In 2013, Chinese free trade area in Shanghai trial more open cross-border trade policy, the next step for opening up the e-commerce market. At the same time, China has gradually liberalized foreign capital into the field of electricity shares than the restrictions in the Shanghai FTA, the operating e-commerce investment is no cap. From the customs supervision point of view, in the FTA will also be through the policy business innovation and information technology innovation to improve regulatory efficiency and enhance cross-border transaction process efficiency. In the 
payment process, China will also pay the policy level to protect the speed and security.

Chinese cross-border e-commerce market structure is relatively concentrated in order to export markets and B2B-based, although in recent years B2C model has been great development, but relatively small scope of business. Most of Chinese SMEs in the foreign trade situation is bad, only to embark on the trade of ecommerce transactions, so many cross-border electronic transactions can be seen as an extension of traditional foreign trade. In the import sector, the size of crossborder e-commerce will be much smaller. Chinese cross-border business operators, including four, that is, third-party service platform model, B2B or C2C model (small transactions), bulk B2B and independent B2C model. At present, Chinese cross-border business model is still the main provider of information platform, but with the cross-border business policy continues to improve for the new trade model of import and export customs model, and the establishment of payment system, cross- Will provide more functionality, not only to provide transactions, while providing marketing, payment and logistics and other related services, and these will undoubtedly enhance the convenience of cross-border electricity business, driven by cross-border rapid growth of electronic business transactions, To ensure that Chinese exports remained stable and sustained rise.

\section{The Impact of Cross - border E-commerce on New Norms Economic Development}

The positive development of cross-border e-commerce is conducive to enhancing the competitive advantage of Chinese foreign trade enterprises in terms of cost and efficiency and improving the profitability of enterprises. At the same time, the deep penetration of e-commerce channels can make enterprises and the final consumption between the establishment of more smooth information exchange platform, enabling enterprises to grasp the market demand, adjust product structure according to demand, improve product quality, establish brand and ecommerce Credit system, thereby enhancing the overall competitiveness of Chinese foreign trade, to promote the steady growth of foreign trade plays an important role.

The cross-border e-commerce is an effective way to break the channel monopoly, which can reduce intermediate links, reduce transaction costs and save transaction time. It can provide new opportunities for Chinese enterprises to establish brand and enhance brand awareness. Thus enhance their international competitiveness.

Cross-border e-commerce directly contributed to the logistics and distribution, e-payment, e-certification content services and other modern information services and related electronic information manufacturing industry. At present, Chinese ecommerce platform has more than 5,000 enterprises. With a number of wellknown e-commerce platform enterprises, logistics courier, third-party payment of local enterprises rapid rise, cross-border e-commerce will promote the production 
methods and industrial organization changes. In order to meet the diversified and individualized needs of overseas consumers, the enterprise should take the consumer as the center, strengthen the cooperation innovation, improve the service system, not only to enhance the product manufacturing process and quality, but also to strengthen R \& D and brand sales, Chain and industrial chain, and promote enterprises to optimize the allocation of resources.

\section{The Basic Factors Affecting the Development of Chinese Cross-border E-commerce}

Cross-border e-commerce trading model has undergone great changes, buyers and sellers directly through the online platform for transactions, consumers will no longer be faced with importers and distributors, but the supply of direct suppliers or manufacturers, which But also led to the entire cross-border ecommerce in the industrial chain and the supply chain of great changes. The direct transaction between the individual supplier and the customer is bound to manifest as a decrease in the transaction volume and an increase in the frequency. This has brought great convenience to both sides of supply and demand, can change the transaction amount according to market demand, but it has brought great trouble to the customs, the workload also increased a lot. Customs shoulders the responsibility of supervision and taxation, so it is very cautious for customs clearance of goods, must ensure that customs clearance of goods in line with national law. And customs supervision procedures also need time to implement, which to some extent can not meet the requirements of cross-border e-commerce. A large number of goods by courier or mail the way out of customs, for the supervision of small pieces of how to apply what the tax rate, when the return issue how to return home, the existing customs supervision mode can be clear, are to be further solve.

Logistics usually includes warehousing, sorting, packaging and distribution links, is connected to buyers and sellers an important bridge link in e-commerce occupies an important position. With the prosperity of domestic e-commerce, gave birth to a large number of private logistics enterprises, driven by the continuous upgrading of the logistics industry, not only to meet the needs of modern logistics diversity and agility, but also to a certain extent, reduce logistics costs and risks. However, cross-border logistics is difficult, the lack of more logistics options, in order to meet customer needs, can only rely on more monotonous logistics model, that is, more use of air transport mode. Due to the explosive growth in the number of cross-border goods, the current logistics infrastructure and systems are unable to meet such flows, and the logistics sector is often overloaded, resulting in a large backlog of goods or delays in delivery. There is also the same problem with the domestic logistics for the packing and sorting of goods. In the process of long-distance transport, because the packaging does not meet the requirements or violence caused by the sorting of goods damage is not uncommon, especially in cross-border transactions also exist 
Diaobao and other risks, the risk of consumer goods due to distance doubled, All of these affect consumers' views on cross-border transactions, which seriously restrict the long-term development of cross-border e-commerce.

Cross-border electronic payment is not only related to the transfer of funds between the parties to the transaction security, e-commerce is also different from the core of traditional trade. The traditional way of trade, cash flow is often by virtue of eligible documents, to the designated bank for payment of funds, funds are handled by the bank, by the parties themselves to handle. However, in crossborder electronic transactions, the two sides do not understand each other's credit counterparties, the transaction is unlikely to both sides for a very small amount of cumbersome security procedures experienced, the seller is likely to not receive the purchase price, or the buyer in the payment But not received after the payment of goods, both sides of the transaction has significant credit uncertainty. China does not have a unified management standard for cross-border payments, there is no clear cross-border business scope and the amount of margin, the entire transaction process depends on third-party payment, and third-party payment technically far from the network transfer of funds smoothly, It is impossible to ensure the safety of online transactions by providing perfect information for both domestic and foreign parties, not enough cooperation with banks, coupled with the virtual nature of online transactions and the rapid transfer of funds on the Internet, without solving these technical problems.

\section{Conclusion}

Under the new economic growth pressure and other normal conditions, the inherent shortcomings of Chinese foreign trade model have become increasingly prominent. Through the transformation of foreign trade growth model to achieve by the foreign trade power to the trade power leap, is the only way to crack the crux of foreign trade growth fatigue, which requires the introduction of relevant government policies to guide e-commerce market innovation model for Chinese foreign trade transformation and upgrading service. Cross-border e-commerce is in the import and export of stagnant environment to achieve counter-attack, as mainland enterprises to open up new channels of international markets and accelerate the transformation of foreign trade development approach.

\section{References}

[1] Gomez-Herrera, Estrella. The drivers and impediments for cross-border ecommerce inthe EU [J]. Information Economics \& Policy, Sep2014, Vol. 28, $\mathrm{p} 83-96$

[2] Huang, Xiaodi. Bula Pay: a novel web service based third-party payment system fore-commerce [J].Electronic Commerce Research. Dec2014, Vol. 14 Issue 4, p611-633. 
[3] O'Connor, Clare.Alibaba's Latest E-Commerce Coup: Secure Mobile Payment by Fingerprint [J]. Forbes.com. 9/2/2014, p1-1. 1p. 1 Color Photograph.

[4] Stylianou, Paul. Online dispute resolution:The case for a treaty between the UnitedStates and the European Union in resolving cross-border e-commerce disputes. Syracuse Journal of International Law \& Commerce [J]. Fall2008, Vol. 36Issue 1, p117-143

[5] Wong David W.C. Assessing a cross-border logistics policy using a performance measurement system framework: the case of Hong Kong and the Pearl River Deltaregion [J].International Journal of Systems Science. Jun2014, Vol. 45 Issue 6,p1306-1320. 